УДК 342.2:336.222

DOI https://doi.org/10.32849/2663-5313/2019.12.30

\title{
Віктор Бернадін,
}

ад'юнкт кафедри публічного управління та адміністрування

Національної академії внутрішніх справ

\section{ПОНЯТТЯ ТА КЛАСИФІКАЦІЯ АДМІНІСТРАТИВНИХ ПРАВОПОРУШЕНЬ У СФЕРІ ОБІГУ ПІДАКЦИЗНИХ ТОВАРІВ}

у статті розглядаються проблемні питання визначення поняття «адміністративне правопорушення у сфері обігу підакиизних товарів», а також наводиться класифікачія таких правопорушень. Запропоновано визначити адміністративне правопорушення у сфері обізу підакиизних товарів як суспільно-шкідливу, протиправну, винну дію чи бездіяльність, що порушує адміністративно-правові норми у сфері регулювання обігу підакиизних товарів та за яку законодавством встановлено адміністративну відповідальність. До вказаних адміністративних правопорушень запропоновано відносити правопорушення, що порушують встановлений порядок імпорту, експорту, транспортування, зберігання, продажу та інших видів діяльності, що здійснюються по відношенню до підакцизних товарів. До вказаної категорії товарів належать спирт етиловий та інші спиртові дистиляти, алкогольні напої, пиво; тютюнові вироби, тютюн та промислові замінники тютюну; пальне; автомобілі легкові, кузови до них, причепи та напівпричепи, мотоцикли, транспортні засоби, призначені для перевезення 10 осіб $і$ більше, транспортні засоби для перевезення вантажів; електрична енергія. Досліджено критерії та окремі види класифікацій адміністративних правопорушень у сфері обігу підакиизних товарів. Визначено критерії поділу зазначених правопорушень на види: тривалість вчинення того чи іншого припорошення, форма вчинення протиправного діяння, характер шкідливих наслідків вчиненого діяння, особливості суб'єктів вчинення порушень митних правил, а також об'єкт посягання. За останнім критерієм запропоновано класифікацію таких правопорушень з поділом їх на такі групи: - правопорушення, що пов'язані з обігом спирту етилового та інших спиртових дистилятів, алкогольних напоїв, пива, а також тютюнових виробів, тютюну та промислових замінників тютюну; правопорушення, які пов'язані з обігом пального та електричної енергії; митні правопорушення, що пов'язані з обігом підакиизних товарів.

Ключові слова: адміністративне правопорушення, податкове правопорушення, митне правопорушення, адміністративна відповідальність, підакцизні товари.

Постановка проблеми. Важливим джерелом наповнення Державного бюджету України є акцизний збір, а тому правопорушення у сфері обігу підакцизних товарів заподіюють безпосередню шкоду державній фінансовій системі. Крім того, вони також створюють загрозу завдання шкоди правам та інтересам споживачів таких товарів.

До підакцизних товарів, згідно зі ст. 215 Податкового кодексу України, належать: спирт етиловий та інші спиртові дистиляти, алкогольні напої, пиво (крім квасу «живого» бродіння); тютюнові вироби, тютюн та промислові замінники тютюну; пальне; автомобілі легкові, кузови до них, причепи та напівпричепи, мотоцикли, транспортні засоби, призначені для перевезення 10 осіб і більше, транспортні засоби для перевезення вантажів; електрична енергія [1]. Обіг же зазначених товарів - це їх імпорт, експорт, транспортування, зберігання, про- даж та інші види діяльності, що здійснюються по відношенню до даних товарів.

У науковій літературі фактично відсутні комплексні дослідження питань адміністративної відповідальності за правопорушення у сфері обігу усіх вказаних підакцизних товарів. Вони розглядаються фрагментарно, приу межах дослідження конкретних видів такого роду правопорушень. Наприклад, правопорушення у сфері обігу алкогольних напоїв та тютюнових виробів або правопорушення у митній чи податковій сфері. Окремим питанням адміністративно-правової протидії правопорушенням у сфері обігу підакцизних товарів приділяли увагу такі вчені, як О.М. Бандурка, О.Ю. Дрозд, С.В. Ківалов, В.К. Колпаков, О.В. Кузьменко, С.І. Лепський, Ю.С. Шемшученко, С.А. Шепетько та інші. Проте залишається потреба в науковій розробці комплексних питань реалізації механізму адміністративної відповідальності 
за правопорушення у сфері обігу підакцизних товарів.

Метою статті $\epsilon$ визначення поняття адміністративних правопорушень у сфері обігу підакцизних товарів, а також проведення їх класифікації з урахуванням особливостей об'єктивних та суб'єктивних ознак цих правопорушень.

Виклад основного матеріалу. Адміністративна відповідальність за порушення норм у сфері обігу даної категорії товарів характеризується певними особливостями, перша з яких пов'язана з існуванням різних за своєю суттю законодавчих актів. Найбільш поширеними у наукових джерелах визначають такі види адміністративних правопорушень у сфері обігу підакцизних товарів: порушення використання товарно-транспортних накладних за формою 1-ТН (алкогольні напої); реалізація алкогольних напоїв на підставі ліцензії на право роздрібної торгівлі у місці торгівлі, площа якого є меншою 20 м $^{2}$; здійснення роздрібної торгівлі тютюновими виробами за цінами, вищими від максимальних роздрібних цін на тютюнові вироби, встановлених виробниками або імпортерами таких тютюнових виробів, збільшеними на суми акцизного податку з реалізації через роздрібну торговельну мережу; порушення вимоги зберігання підакцизних товарів у місцях зберігання, не внесених до Єдиного державного реєстру місць зберігання тощо [2].

Проте наведений порядок розмежування правопорушень у сфері обігу підакцизних товарів не має ознаки системності та наукової обгрунтованості, крім того, в ньому міститься значна кількість фінансових правопорушень, а не адміністративних. Тому пропонується визначити можливий перелік адміністративних правопорушень у сфері обігу підакцизних товарів з використанням системного підходу в побудові відповідної класифікації. У наукових дослідженнях приділяється недостатня увага до такої класифікації, проте досить детально розглядається питання доктринальних підходів до класифікації адміністративних правопорушень у сфері оподаткування.

Фактично Податковим Кодексом України від 2 грудня 2010 року № 2755-VI визначається три види правопорушень у сфері оподаткування - це фінансові, адміністративні та кримінальні, що випливає зі змісту глави 11 цього нормативно-правового акта [1]. Більш детальна класифікація наводиться науковцями у дослідженні особливостей цього виду правопорушень.

Наприклад, В.В. Іщенко пропонує класифікувати адміністративні правопорушення у сфері оподаткування за видовими об'єктами на такі групи: 1) адміністративні правопорушення проти порядку ведення податкового обліку, складання та подання податкової звітності (ст. 163-1, 163-2 КУПАП); 2) адміністративні правопорушення проти обов'язків зі сплати податків та подання декларацій про доходи та майновий стан (ст. 163-4, 164-1, ч. 1, 3, 4 ст. 172-6 КУ 3) адміністративні правопорушення проти контрольних функцій податкових органів (ст. 163-3, ч. 5-9 ст. 166-6, ст. 188-23 КУпАП); 4) адміністративні правопорушення у сфері виробництва та збуту алкогольних напоїв та тютюнових виробів (ст. 156, 156-2, 164-5, 177-2 КУПАП); 5) адміністративні правопорушення проти прав та свобод платників податків (ч. 9, 10 ст. 166-6, ст. 166-21 КУПАП) [3, c. 144].

Запропонована класифікація є досить вдалою та заслуговує на увагу в контексті даного дослідження. Проте важко погодитися 3 позицією автора щодо доцільності встановлення додаткової адміністративної відповідальності за правопорушення проти системи оподаткування (під якими пропонується розуміти: незаконне встановлення та/або введення податків, незаконне стягнення податків, незаконне звільнення від сплати податків), а також правопорушення проти виконання дохідної частини бюджету (наприклад, незаконне використання коштів, що надійшли на сплату податків податковими агентами або банками).

Інші ж класифікації вважають менш вдалими та не виокремлюють таку сферу діяльності, як обіг підакцизних товарів. Зокрема I. Лонюк наводить таку класифікацію податкових адміністративних правопорушень за суб'єктами, які їх вчиняють: 1) правопорушення, за вчинення яких відповідальність несуть лише керівники та інші посадові особи; 2) правопорушення, за вчинення яких відповідальність несуть лише посадові особи i громадяни - суб'єкти підприємницької діяльності; 3) правопорушення, за вчинення яких відповідальність несуть лише громадяни, які займаються підприємницькою діяльністю; 4) правопорушення, за вчинення яких відповідальність несуть лише громадяни [4, с. 34].

Значна увага науковцями приділяється класифікації, яка запропонована С.Г. Пепеляевим. Ним визначено, що податкові правопорушення слід поділяти на: 1) правопорушення проти системи податків; 2) правопорушення проти прав та свобод платників податків; 3) правопорушення проти системи гарантій виконання обов'язків платника податків; 4) правопорушення 
проти виконання дохідної частини бюджету; 5) правопорушення проти контрольних функцій податкових органів; 6) правопорушення проти порядку ведення бухгалтерського обліку, складання та подання бухгалтерської та податкової звітності; 7) правопорушення проти обов'язків зі сплати податків [5, с. 95; 6, с. 208].

Дослідження наведених класифікацій, а також вивчення сфери обігу підакцизних товарів як об'єкта адміністративноправової охорони дає підстави взяти за основу класифікацію, що була запропонована В. В. Іщенко, з деякими зауваженнями та уточненнями. Слід погодитися з позицією дослідника щодо розподілу адміністративних правопорушень у сфері оподаткування за видовими об'єктами, проте пропонується замість такого виду, як адміністративні правопорушення у сфері виробництва та збуту алкогольних напоїв та тютюнових виробів, окремо виділити адміністративні правопорушення у сфері обігу підакцизних товарів. Разом із тим залишається вирішити питання щодо визначення переліку правопорушень, які слід віднести до даного виду.

Варто розпочати з аналізу суспільних відносин, що існують у сфері обігу підакцизних товарів та яким може заподіюватись шкода відповідними правопорушеннями. Слід враховувати, що п. 215.1 ст. 215 Податкового кодексу України до підакцизних товарів відносить: спирт етиловий та інші спиртові дистиляти, алкогольні напої, пиво; тютюнові вироби, тютюн та промислові замінники тютюну; пальне; автомобілі легкові, кузови до них, причепи та напівпричепи, мотоцикли, транспортні засоби, призначені для перевезення 10 осіб і більше, транспортні засоби для перевезення вантажів; електричну енергію [1]. Відповідно, під обігом підакцизних товарів слід розуміти будь-яку діяльність щодо виготовлення, імпорту, експорту, транспортування, зберігання, збуту та розповсюдження даних товарів. Тому правопорушення у сфері обігу підакцизних товарів мають посягати на суспільні відносити у визначених видах діяльності та мати таку обов'язкову ознаку, як предмет правопорушення - підакцизний товар, для того щоб їх можна було віднести до досліджуваної групи правопорушень.

Визначення відповідного переліку адміністративних правопорушень у сфері обігу підакцизних товарів можна здійснити через аналіз нормативно-правових актів, якими встановлюється відповідальність за їх вчинення.

Насамперед слід звернути увагу на Кодекс України про адміністративні право- порушення. У межах цього нормативно-правового акта можливо виділити кілька підвидів адміністративних правопорушень у сфері обігу підакцизних товарів.

По-перше, це правопорушення, що пов’язані з обігом спирту етилового та інших спиртових дистилятів, алкогольних напоїв, пива, а також тютюнових виробів, тютюну та промислових замінників тютюну. Дану групу пропонується визначити як правопорушення у сфері обігу алкогольних напоїв та тютюнових виробів та включити до неї:

- порушення правил торгівлі пивом, алкогольними, слабоалкогольними напоями і тютюновими виробами (ст. 156 КУ ПАП);

- порушення встановленого порядку промислової переробки, зберігання, транспортування або знищення конфіскованих спирту, алкогольних напоїв чи тютюнових виробів (ст. 156-2 КУПАП);

- порушення встановленого порядку промислової переробки, зберігання, транспортування або знищення конфіскованих спирту, алкогольних напоїв чи тютюнових виробів (ст. 156-3 КУпАП);

- порушення порядку провадження господарської діяльності (ст. 164 КУпАП, в частині діяльності, пов'язаної з обігом алкогольних напоїв та тютюнових виробів);

- зберігання або транспортування алкогольних напоїв чи тютюнових виробів, на яких немає марок акцизного збору встановленого зразка (ст. 164-5 КУпАП);

- випуск у продаж продукції 3 порушенням вимог щодо медичних попереджень споживачів тютюнових виробів (ст. 168-2 КУПАП);

- виготовлення, зберігання самогону та апаратів для його вироблення (ст. 176 КУПАП);

- придбання самогону та інших міцних спиртних напоїв домашнього вироблення (ст. 177 КУПАП);

- виготовлення, придбання, зберігання або реалізація фальсифікованих алкогольних напоїв або тютюнових виробів (ст. 177-2 КУПАП).

По-друге, це адміністративні правопорушення, які пов'язані з обігом пального та електричної енергії, до яких можна віднести:

- порушення правил користування енергією, водою чи газом (ст. 103-1 КУПАП);

- незаконний відпуск або придбання бензину чи інших паливно-мастильних матеріалів (ст. 161 КУпАП);

- порушення порядку провадження господарської діяльності (ст. 164 КУПАП, в частині діяльності, пов'язаної з обігом пального) 
Крім КУпАП, відповідальність за адміністративні правопорушення у сфері обігу підакцизних товарів також встановлена у Митному кодексі України. Адже у ст. 458 цього кодексу визначається, що порушення митних правил $є$ адміністративним правопорушенням [7].

У даних нормативно-правових актах по-різному визначається поняття адміністративного правопорушення, на що звертають увагу окремі науковці [8, с. 193]. Так, у ст. 9 КУпАП адміністративне правопорушення визначається як протиправна, винна (умисна або необережна) дія чи бездіяльність, яка посягає на громадський порядок, власність, права і свободи громадян, на встановлений порядок управління і за яку законом передбачено адміністративну відповідальність [9]. Відповідно, у ст. 458 МКУ під адміністративним правопорушенням розуміються протиправні, винні (умисні або 3 необережності) дії чи бездіяльність, що посягають на встановлений МКУ та іншими актами законодавства України порядок переміщення товарів, транспортних засобів комерційного призначення через митний кордон України, пред'явлення їх органам доходів і зборів для проведення митного контролю та митного оформлення, а також здійснення операцій з товарами, що перебувають під митним контролем або контроль за якими покладено на органи доходів і зборів МКУ чи іншими законами України, і за які МКУ передбачена адміністративна відповідальність [7].

Враховуючи зазначене, під адміністративним правопорушенням у сфері обігу підакцизних товарів слід розуміти суспільно-шкідливу, протиправну, винну дію чи бездіяльність, що порушує адміністративно-правові норми у сфері регулювання обігу підакцизних товарів та за яку законодавством встановлено адміністративну відповідальність.

У Митному кодексі України не визначаються особливості відповідальності за правопорушення саме за порушення обігу підакцизних товарів. Разом із тим порушення, передбачені розділом XVIII «Порушення митних правил та відповідальність за них» Митного кодексу України, досить часто бувають пов'язані з порушеннями порядку обігу підакцизних товарів, а саме їх імпорту чи експорту.

Загалом, за об'єктом посягання науковцями пропонується виділяти такі групи адміністративних правопорушень у Митному кодексі України:

- порушення, що посягають на встановлений порядок переміщення товарів і тран- спортних засобів комерційного призначення через митний кордон України (ст. 473, 477, 482, 483);

- порушення, що посягають на встановлений порядок здійснення митного контролю та оформлення (ст. 471, 474, 475, 470, 472);

- порушення, що посягають на встановлений порядок здійснення операцій з товарами, що перебувають під митним контролем (ст. 469, 477, 480);

- порушення, що посягають на встановлений порядок оподаткування та надання митних пільг (ст. 481, 484, 485) [10, с. 467].

У наукових джерелах також можна зустріти інші критерії поділу зазначених правопорушень на види: тривалість вчинення того чи іншого правопорушення, форма вчинення протиправного діяння, характер шкідливих наслідків вчиненого діяння, а також особливості суб'єктів вчинення порушень митних правил.

\section{Висновки}

Підсумовуючи викладене, слід зазначити, що аналіз наведених наукових позицій щодо визначення поняття та класифікації адміністративних правопорушень у сфері обігу підакцизних товарів дає змогу сформулювати такі висновки.

Адміністративне правопорушення у сфері обігу підакцизних товарів - це суспільношкідлива, протиправна, винна дія чи бездіяльність, що порушує адміністративно-правові норми у сфері регулювання обігу підакцизних товарів та за яку законодавством встановлено адміністративну відповідальність.

До адміністративних правопорушень у сфері обігу підакцизних товарів слід відносити правопорушення, що порушують встановлений порядок імпорту, експорту, транспортування, зберігання, продажу та інших видів діяльності, що здійснюються по відношенню до підакцизних товарів, та відповідальність за які встановлюється адміністративним законодавством.

Адміністративні правопорушення у сфері обігу підакцизних товарів слід поділяти на такі види:

- правопорушення, що пов'язані з обігом спирту етилового та інших спиртових дистилятів, алкогольних напоїв, пива, а також тютюнових виробів, тютюну та промислових замінників тютюну (статті 156, 156-2, 156-3, 164, 164-5, 168-2, 176, 177, 177-2 КУПАП);

- правопорушення, які пов'язані з обігом пального та електричної енергії (статті 103-1, 161, 164 КУ ПАП);

- митні правопорушення, що пов'язані 3 обігом підакцизних товарів (статті 473 485 МКУ). 


\section{Список використаних джерел:}

1. Податковий кодекс України від 02.12.2010 № 2755-VI. Відомості Верховної Ради України. 2011. № 13-17. Ст. 112.

2. Підакцизні товари: наслідки порушень. Вісник. Офіційно про податки : офіційне видання державної фіскальної служби. URL: http:// www.visnuk.com.ua/uk/publication/100004916pidaktsizni-tovari-naslidki-porushen (дата звернення: 09.11.2019).

3. Іщенко В.В. Класифікація адміністративних правопорушень у сфері оподаткування: доктринальні підходи. Порівняльне-аналітичне право. 2017. №1. C. 142-145. URL: http:// www.pap.in.ua/1_2017/44.pdf (дата звернення: 09.11.2019).

4. Лонюк І. Відповідальність за порушення податкового законодавства. Вісник податкової служби України. 2001. № 26. С. 33-34.

5. Пепеляев С.Г. Предложения по проекту Налогового кодекса. Ответственность за нарушения налогового законодательства. Выпуск первый / отв. ред. В.Ф. Захарова. Москва, 1996. C. $87-101$
6. Пепеляев С.Г. Налоговый кодекс: взаимная ответственность. Ваш налоговый адвокат. Советы юристов : сб. статей. Выпуск 1. Москва ФБК-ПРЕСС, 1997. С. 203-217.

7. Митний кодекс України від 13.03.2012 № 4495-VI. Відомості Верховної Ради України. 2012. № 44-48. Ст. 552.

8. Джурик О.Р. Особливості адміністративної відповідальності за правопорушення у сфері державної митної справи. Порівняльно-аналітичне право. 2016. № 5. С. 192-195.

9. Кодекс України про адміністративні правопорушення від 07.12.1984 № 8073-X / Офіційний веб-портал Верховної Ради України. URL: https://zakon.rada.gov.ua/laws/main/80731-10 (дата звернення: 09.11.2019).

10. Зотенко О. О. Класифікація порушень митних правил. Критерії розмежування «триваючих» та «разових» ПМП. Правове життя сучасної України : матеріали Міжнар. наук. конф. проф.викл. та аспірант. складу (м. Одеса, 16-17 травня 2013 р.) / відп. за вип. В. М. Дрьомін ; НУ «ОЮА». Півд. регіон. центр НАПрН України. Одеса : Фенікс, 2013. Том 1. С. 467-468.

The article views the problematic issues of definition of the term "administrative offense in the field of circulation of excisable goods", and also provides a classification of such offenses. It is proposed to define an administrative offense in the sphere of circulation of excisable goods as socially harmful, unlaw ful, guilty act or omission, which violates the administrative and legal norms in the sphere of regulation of circulation of excisable goods, and for which the legislation establishes administrative responsibility. These administrative offenses are proposed to include offenses that violate the established order of import, export, transportation, storage, sale and other activities carried out in relation to excisable goods. Ethanol and other alcoholic distillates, alcoholic beverages, beer are included in the specified category of goods; tobacco, tobacco and industrial tobacco substitutes; fuel; cars, bodies, trailers and semi-trailers, motorcycles, vehicles intended for the carriage of 10 persons or more, vehicles for the carriage of goods; electrical energy. Criteria and separate types of classifications of administrative offenses in the field of circulation of excisable goods are investigated. The existing criteria for the division of these offenses into types are determined: depending on the duration of committing one or another offense, on the form of committing the unlaw ful act, depending on the nature of the harmful consequences of the committed act, on the peculiarities of the subjects of committing violations of customs rules, as well as on the object encroachment. Taking into account the latter criterion, the classification of such offenses is proposed, with their division into the following groups: - offenses related to the circulation of ethyl alcohol and other alcoholic distillates, alcoholic beverages, beer, as well as tobacco, tobacco and industrial substitutes; offenses related to the circulation of fuel and electricity; customs offenses related to the circulation of excisable goods.

Key words: administrative offense, tax offense, customs offense, administrative liability, excisable goods. 